\title{
ANALISIS FAKTOR END-USER COMPUTING SATISFACTION TERHADAP KEPUASAN PENGGUNA: STUDI KASUS KANTOR PELAYANAN PAJAK MADYA BALIKPAPAN
}

\author{
Anggraeni Purfita Sari \\ Direktorat Jenderal Pajak
}

Muhammad Anshar Syamsuddin

Politeknik Keuangan Negara STAN

Alamat Korespondensi: anshar@pknstan.ac.id

\section{INFORMASI ARTIKEL}

Diterima Pertama

02-01-2018

Dinyatakan Diterima

17-01-2018

KATA KUNCl:

Aplikasi Phinisi, End User Computing Satisfaction

(EUCS), voluntary use

KLASIFIKASI JEL:

C100; $\mathrm{H} 270$

\section{ABSTRAK}

Phinisi application is a tax information management system that beneficial to monitor the administration of incoming and outgoing mails among sections in one office. It can also facilitate in monitoring of tax revenue, and assist Account Representative (AR) in the issuance of Tax Assessment (STP). As one of the voluntary-based information systems, the success of this system highly depends on user satisfaction throughout measurable-system evaluation. This kind of evaluation will also be useful for future system improvements. In this research, user satisfaction of application at KPP Madya Balikpapan will be measured by using End User Computing Satisfaction (EUCS) model which consists of five factors, they are: content, form, accuracy, ease and timeliness through descriptive quantitative method. Questionnaires distributed to application users in KPP Madya Balikpapan and then processed using Ms. Excel and SmartPLS 3. The results show that each variable that is content, form, accuracy, ease of use and timeliness have a positive and significant effect on end-user application satisfaction.

Aplikasi Phinisi merupakan sistem informasi manajemen perpajakan yang digunakan untuk memantau administrasi surat masuk dan keluar antar seksi dalam satu kantor, mempermudah monitoring penerimaan pajak, serta membantu Account Representative (AR) dalam penerbitan Surat Tagihan Pajak (STP). Sebagai salah satu sistem informasi yang bersifat voluntary use, kesuksesan sistem ini sangat tergantung pada kepuasan pengguna melalui evaluasi sistem yang terukur. Evaluasi semacam ini juga akan berguna bagi perbaikan sistem ke depannya. Dalam penelitian ini kepuasan pengguna aplikasi di KPP Madya Balikpapan akan diukur dengan menggunakan model End User Computing Satisfaction (EUCS) yang terdiri dari lima faktor yaitu faktor isi, bentuk, keakuratan, kemudahan serta ketepatan waktu melalui metode kuantitatif deskriptif. Kuesioner disebarkan kepada pengguna aplikasi di lingkungan KPP Madya Balikpapan kemudian diolah menggunakan aplikasi Ms. Excel dan SmartPLS 3. Hasil pengolahan menunjukkan bahwa masing-masing variabel yaitu variabel isi, bentuk, keakuratan, kemudahan serta ketepatan waktu berpengaruh secara positif dan signifikan terhadap kepuasan pengguna akhir aplikasi. 


\section{PENDAHULUAN}

\subsection{Latar Belakang}

Penggunaan End-User Computing (EUC) pada lingkup Direktorat Jenderal Pajak (DJP) ditengah kemajuan teknologi seperti saat ini adalah sebuah hal yang sulit dihindari. Semakin mudah dan cepatnya akses internet membuat semakin mudahnya tutorial pembuatan dan pengembangan sebuah aplikasi didapat. Hal ini berarti semakin banyak pula orang yang bisa membuat program di komputernya sendiri untuk mempermudah pekerjaannya. Hasil pengembangan program ini tak jarang kemudian digunakan dalam lingkup yang lebih luas, dari mulai digunakan oleh rekan satu seksi, satu kantor, satu kanwil hingga tidak menutup kemungkinan dimanfaatkan pula oleh sesama pegawai DJP pada lingkup nasional.

DJP sendiri telah mengakomodasi penggunaan EUC ini dengan menerbitkan Surat Edaran Direktur Jenderal Pajak dengan nomor SE-6/PJ/2011 sebagaimana telah diperbarui dengan SE-08/PJ/2016 mengenai Pedoman Pengelolaan End User Computing (EUC). Surat ini memungkinkan pengembangan teknologi informasi dan komunikasi selain oleh Direktorat TTKI dengan syarat tertentu, misalnya syarat tentang perizinan, kerahasiaan data dan lain sebagainya.

Hal lain yang menarik dari EUC ini adalah kenyataan bahwa seringkali EUC dikembangkan karena adanya kebutuhan user akan sebuah sistem informasi yang tidak atau belum difasilitasi oleh sistem yang telah dikembangkan oleh Kantor Pusat DJP. Sistem informasi yang bersifat mandatory seperti Sistem Informasi Direktorat Jenderal Pajak (SIDJP) yang ada terkadang belum cukup untuk memenuhi keinginan user. EUC yang dikembangkan sendiri oleh pengguna akhir ini kemudian menjadi jawaban atas kebutuhan user yang menginginkan akses informasi yang lebih cepat dan mudah daripada sistem yang telah ada berdasarkan hasil wawancara dengan pelaksana di KPP di wilayah Kanwil DJP Kaltim dan Utara.

Di wilayah kerja Kanwil DJP Kalimantan Timur dan Utara, sekurang-kurangnya terdapat 6 EUC berbentuk aplikasi web dan atau dekstop yang digunakan, belum termasuk aplikasi yang berbentuk Ms. Excel. Dua di antaranya yang memiliki pengguna terbanyak adalah aplikasi Phinisi dan aplikasi MPN-Info. Berikut ini adalah daftar EUC yang penulis peroleh dari wawancara dengan pelaksana dari delapan Kantor Pelayanan Pajak (KPP) di wilayah Kanwil DJP Kaltim dan Utara.

Tabel 1. Daftar Penggunaan EUC di Kanwil Kaltim dan Utara

\begin{tabular}{|c|c|c|}
\hline No & Nama EUC & Jumlah KPP Pengguna \\
\hline 1 & Aplikasi MPN-Info & $8 \mathrm{KPP}$ \\
\hline 2 & Aplikasi Phinisi & $5 \mathrm{KPP}$ \\
\hline 3 & $\begin{array}{l}\text { Aplikasi Database Persediaan, Pengiriman Surat } \\
\text { dan Perbaikan Kendaraan }\end{array}$ & $1 \mathrm{KPP}$ \\
\hline 4 & Aplikasi $W e b$ Samara & $1 \mathrm{KPP}$ \\
\hline 5 & Aplikasi ProfileWP & $1 \mathrm{KPP}$ \\
\hline 6 & Aplikasi Surat Masuk dan Keluar & $1 \mathrm{KPP}$ \\
\hline
\end{tabular}

Sumber: KPP di wilayah Kaltim dan Utara
Dari data di atas, peneliti kemudian mengambil fokus penelitian pada satu aplikasi, yaitu aplikasi Phinisi. Pertimbangan yang diambil penulis adalah aplikasi Phinisi ini dikembangkan oleh pegawai di lingkungan KPP dalam Kanwil DJP Kaltim dan Utara, sedangkan aplikasi MPN-Info sekalipun penggunanya lebih luas, aplikasi ini dikembangkan oleh pegawai di luar Kanwil DJP Kaltim dan Utara serta pernah diteliti sebelumnya oleh penulis lain. Penelitian sebelumnya telah dilakukan oleh Ari Kuswantoro pada tahun 2016 yang meneliti Pengaruh Persepsi Kemanfaatan Dan Persepsi Kemudahan Penggunaan Terhadap Penerimaan MPN-Info Di Lingkungan Kanwil DJP Sulawesi Selatan, Barat, Dan Tenggara dengan model TAM.

Melihat dari banyaknya pengguna aplikasi Phinisi seperti yang terdapat pada tabel 1 serta pentingnya faktor evaluasi kepuasan pengguna untuk menilai kesuksesan aplikasi ini, maka pada penelitian ini akan mengevaluasi kepuasan pengguna aplikasi Phinisi menggunakan salah satu model pengukur kepuasan pengguna, yaitu model EUCS. Variabel-variabel yang ada pada model ini penulis harapkan dapat menjadi tolok ukur untuk mengetahui faktor apa sajakah yang mungkin berpengaruh terhadap kepuasan pengguna aplikasi Phinisi sekaligus untuk mengetahui faktor mana saja yang masih harus diperbaiki untuk penyempurnaan aplikasi ini kedepannya.

Penelitian ini bertujuan untuk mengidentifikasi hubungan antara kepuasan pengguna aplikasi Phinisi pada KPP Madya Balikpapan dengan faktor-faktor pada model EUCS yaitu isi (Content), bentuk (Format), keakuratan (Accuracy), kemudahan penggunaan (Ease of Use), dan ketepatan waktu (Timeliness). Penelitian ini menggunakan model yang berbeda dengan penelitian sebelumnya.

\section{KERANGKA TEORI DAN PENGEMBANGAN HIPOTESIS}

Sistem Informasi menurut McLeod dan (2008) adalah suatu sistem virtual, sedangkan Sistem Informasi Manajemen (SIM) adalah suatu sistem berbasis komputer yang membuat informasi tersedia bagi para pengguna yang memiliki kebutuhan serupa. Sistem informasi manajemen menurut Gordon B. Davis (1985) seperti yang dikutip oleh Rasman $(2012,7)$ adalah "sebuah sistem manusia/mesin yang terpadu (integrated), untuk menyajikan informasi guna mendukung fungsi operasi, manajemen, dan pengambilan keputusan dalam sebuah organisasi.

Direktorat Jenderal Pajak (DJP) sebagai salah satu organisasi pemerintahan modern di bawah Kementerian Keuangan tentu tidak mau kalah dalam pengembangan Sistem Informasinya. Berbagai macam sistem informasi dikembangkan DJP untuk memenuhi kebutuhan stakeholdernya, baik dari kalangan internal misalnya pegawai maupun eksternal seperti wajib pajak. Sistem informasi untuk kalangan internal misalnya adalah SIDJP yang dipakai untuk menyelesaikan pekerjaan sehari-hari, kemudian ada Sistem Informasi Kepegawaian, Keuangan dan Aktiva 
(SIKKA) yang biasanya digunakan untuk mengurus dokumen kepegawaian misalnya dokumen kenaikan pangkat atau permohonan cuti. Selain itu, terdapat pula aplikasi Portal DJP (Apportal) yang biasa digunakan untuk melihat data penerimaan pajak dan masterfile wajib pajak seluruh Indonesia. Sedangkan sistem informasi perpajakan untuk wajib pajak tersedia melalui website pajak.go.id.

End-User Computing (EUC) adalah pengembangan seluruh atau sebagian sistem informasi oleh pengguna (Raymond McLeod dan Schell 2008, 99). Sedangkan menurut SE-08/PJ/2016 mengenai Pedoman Pengelolaan End User Computing (EUC), EUC ini adalah pengembangan sistem berbasis komputer oleh pengguna (end user). Menurut Marshall Romney dan Paul Steinbart (2006) dalam Mary Callahan Hill and W. Alan Barnes $(2011,67)$ : "EUC is [A]n information system developed by the users themselves rather than IT professionals to meet company operational or management information needs. An end-user application often extracts or transfers data from a corporate database as a starting point". Menurut McLeod dan Schell (2008, 99), EUC ini muncul karena empat pengaruh utama, yaitu:
a. Dampak pendidikan komputer
b. Antrian layanan informasi
c. Murahnya perangkat keras
d. Perangkat lunak yang siap pakai

Penggunaan EUC ini mengubah rantai komunikasi pada sistem informasi tradisional. Apabila dalam sistem tradisional tenaga spesialis sistem informasi yang terlibat ada banyak pihak misalnya analis sistem, administrator basis data, webmaster, spesialis jaringan, programmer dan operator, pada EUC rantai ini dipangkas. Spesialis informasi hanya memberikan dukungan sebatas yang dibutuhkan oleh pengguna akhir. Perbedaan tersebut itu dapat dilihat pada gambar 1 dan 2 berikut ini.

Gambar 1. Rantai Komunikasi Tradisional

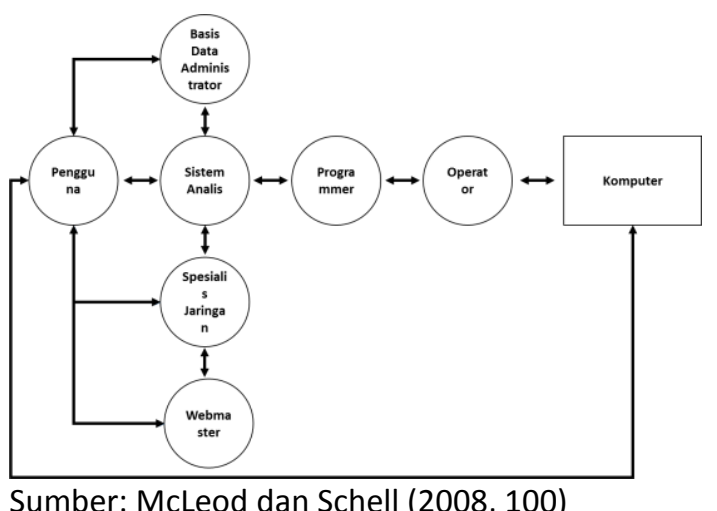

Sumber: McLeod dan Schell $(2008,100)$
Gambar 2. Rantai Komunikasi EUC

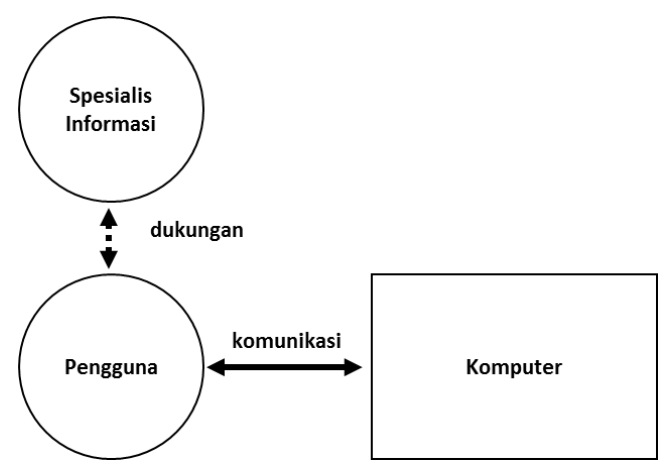

Sumber: McLeod dan Schell $(2008,100)$

McLeod dan Schell $(2008,101)$ mengemukakan dua manfaat EUC dalam studinya. Pertama, EUC menyamakan kemampuan dan tantangan, terutama di antara pengguna akhir dengan spesialis informasi. Kedua, EUC mempersempit jarak komunikasi antara spesialis informasi dengan pengguna, karena ketika sebuah sistem dikembangkan pengguna sendiri, kebutuhan komunikasi dengan spesialis informasi akan berkurang, bahkan hilang. Namun meskipun EUC ini memiliki manfaat, Raymond McLeod dan Schell (2008, 102) juga menguraikan kekurangan dari EUC, yaitu:

a. Saluran sistem yang buruk

b. Sistem yang dirancang dan didokumentasikan dengan buruk

c. Penggunaan sumber daya informasi yang tidak efisien

d. Hilangnya integritas data

e. Hilangnya keamanan

f. Hilangnya kendali

Berdasarkan uraian mengenai EUC ini, penggunaan EUC di DJP yang semakin marak belakangan ini menjadi menarik untuk diteliti, khususnya mengenai kepuasan dari pengguna EUC ini karena EUC ini memang sejak awal dikembangkan oleh pengguna untuk mempermudah pekerjaannya. EUC yang kemudian digunakan oleh banyak orang sekalipun merupakan aplikasi voluntary bukan tidak mungkin dapat berkembang menjadi mandatory, sehingga penelitian akan EUC ini dapat membantu pengembangan sistem tersebut menjadi lebih baik lagi.

Aplikasi Phinisi merupakan salah satu EUC yang dikembangkan oleh seorang pegawai KPP Madya Balikpapan pada tahun 2013. Aplikasi ini berbentuk aplikasi web dan berbentuk modular, sehingga yang utama pada aplikasi ini adalah modulnya. Modul yang sudah dikembangkan terdiri atas tiga modul yaitu modul surat, modul FMA dan modul monesbaru. Ketiga modul inilah yang digunakan oleh pengguna Phinisi di KPP Madya Balikpapan.

Sebelumnya telah ada beberapa penelitian yang menganalisis kepuasan pengguna sebuah sistem informasi dengan menggunakan model EUCS. Tiga penelitian sebelumnya yang digunakan sebagai referensi penelitian ini adalah penelitian yang 
dilakukan oleh Sekundera (2006), Agustina (2006), serta Rasman (2012).

Sekundera (2006) meneliti Penerimaan Pengguna Akhir Dengan Menggunakan Technology Acceptance Model dan End User Computing Satisfaction Terhadap Penerapan Sistem Core Banking Pada Bank ABC. Pada penelitian ini model Technology Acceptance Model (TAM) dan EUCS digabungkan dan memperoleh hasil penelitian variabel akurasi, kemudahan, dan ketepatan waktu dapat mempengaruhi karyawan di Bank $A B C$ dalam penerimaan sistem core banking, namun variabel isi dan bentuk tidak mempengaruhi penerimaan sistem core banking di Bank ABC. Untuk penelitian ini, peneliti mengambil beberapa definisi serta penjelasan dari penelitian yang dilakukan Sekundera (2006) ini.

Agustina (2006) dengan judul “Mengukur Tingkat Kepuasan Pemakai Website Universitas Bina Darma Menggunakan Pendekatan Model Kepuasan Pemakai Akhir Komputer" dan hasil penelitiannya adalah Ada pengaruh yang positif secara parsial dan simultan pada kelima variabel EUCS pada kepuasan pengguna web Universitas Bina Darma. Dari penelitian ini diadopsi beberapa definisi istilah.

Rasman (2012) yang meneliti hubungan unsurunsur End User Computing Satisfaction Terhadap kepuasan pengguna Sistem Informasi Rumah Sakit Di Rumah Sakit Umum Daerah Kota Depok Tahun 2012 dengan hasil penelitian kepuasan responden terhadap SI Rumah Sakit mencapai angka 55,3 \% dengan variabel format memiliki tingkat kepuasan tertinggi dan isi memiliki tingkat kepuasan terendah. Pada penelitian ini selain mengambil beberapa pengertian, peneliti juga mengambil beberapa pertanyaan kuesioner dari Rasman (2012) untuk memperkaya item pertanyaan kuesioner dalam penelitian ini.

Morissan $(2015,15)$ mengutip pernyataan Roger dan Dominick (2011) mendefinisikan hipotesis sebagai "suatu pernyataan formal mengenai hubungan antara variabel, dan diuji secara langsung". Pada penelitian ini, penulis menggunakan 5 variabel bebas yaitu isi (Content), bentuk (Format), keakuratan (Accuracy), kemudahan penggunaan (Ease of Use), dan ketepatan waktu (Timelines) dan satu variabel terikat yaitu kepuasan pengguna. Berdasarkan latar belakang serta rumusan masalah pada bab I, maka hipotesis dapat dirumuskan sebagai berikut:

$\mathrm{H}_{1}=$ Variabel isi (content) aplikasi Phinisi berpengaruh secara positif terhadap kepuasan pengguna aplikasi di KPP Madya Balikpapan

$\mathrm{H}_{2}=$ Variabel bentuk (format) aplikasi Phinisi berpengaruh secara positif terhadap kepuasan pengguna aplikasi di KPP Madya Balikpapan

$\mathrm{H}_{3}=$ Variabel keakuratan (accuracy) aplikasi Phinisi berpengaruh secara positif terhadap kepuasan pengguna aplikasi di KPP Madya Balikpapan

$\mathrm{H}_{4}=$ Variabel kemudahan penggunaan (ease of use) aplikasi Phinisi berpengaruh secara positif terhadap kepuasan pengguna aplikasi di KPP Madya Balikpapan

$\mathrm{H}_{5}=$ Variabel ketepatan waktu (timeliness) aplikasi Phinisi berpengaruh secara positif terhadap kepuasan pengguna aplikasi di KPP Madya Balikpapan.

Dari hipotesis tersebut peneliti membangun suatu kerangka pemikiran yang dapat dilihat pada gambar 3 berikut.

Gambar 3. Kerangka Pemikiran

VARIABEL BEBAS

VARIABEL TERIKAT

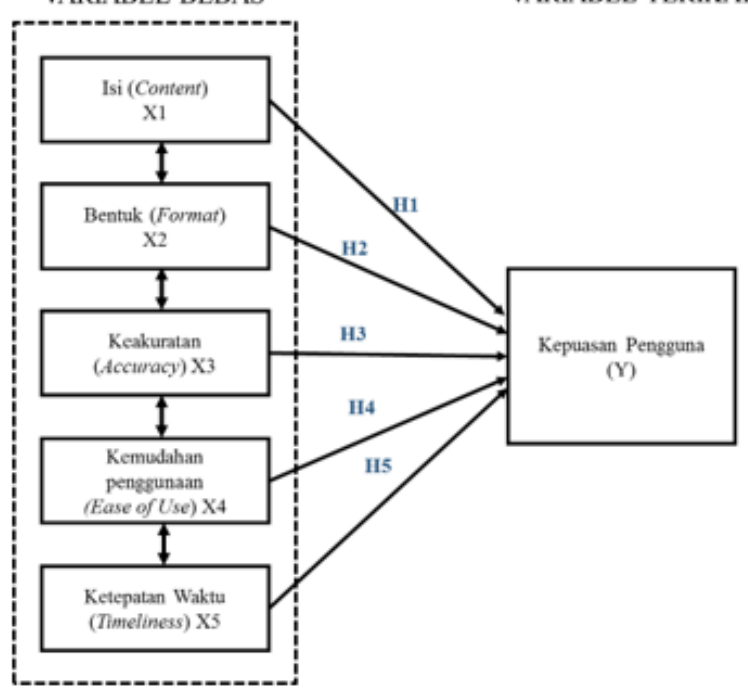

\section{METODE PENELITIAN}

Penelitian ini menggunakan metode penelitian kuantitatif deskriptif. Menurut Morissan (2015, 23) penelitian dengan metode kuantitatif menuntut variabel yang diteliti dapat diukur. Lebih lanjut Morissan $(2015,13)$ menyampaikan bahwa bentuk penelitian ini memberikan perhatian pada seberapa sering suatu variabel muncul dan umumnya menggunakan angka untuk menyampaikan suatu jumlah. Sedangkan penelitian deskriptif menurut Kurniawan $(2015,38)$ mengutip Sugiyono (2014) menyatakan bahwa: "Statistik deskriptif adalah statistik yang digunakan untuk menganalisis data yang telah terkumpul sebagaimana adanya tanpa bermaksud membuat kesimpulan yang berlaku untuk umum atau generalisasi."

Data primer pada penelitian ini diperoleh dari hasil pengisian kuesioner yang dikumpulkan dari responden, yaitu pengguna aplikasi Phinisi pada KPP Madya Balikpapan. Menurut Arikunto (2002, 128) kuesioner merupakan "sejumlah pertanyaan tertulis yang digunakan untuk memperoleh informasi dari responden dalam arti laporan tentang pribadinya, atau hal-hal yang ia ketahui".

Kuesioner yang digunakan berupa kuesioner dengan pertanyaan tertutup sebanyak 17 pertanyaan yang diambil dari penelitian Doll dan Torkzadeh (1988), penelitian Rasman (2012) serta penelitian Chin dan Lee (2000). Peneliti menggabungkan beberapa pertanyaan dari tiga penelitian ini dengan menyesuaikan 
kebutuhan penelitian. Peneliti tidak mengambil hanya dari penelitian aslinya, yaitu penelitian Doll dan Torkzadeh (1988) karena pertanyaan yang ada sangat sedikit yaitu hanya 12 pertanyaan dan memiliki struktur pertanyaan yang serupa sehingga dikhawatirkan hasil jawaban responden akan bias dan terjadi kesalahpahaman atas pertanyaan. Responden nantinya tinggal memilih jawaban yang telah disediakan dalam kuesioner ini namun penulis akan menyisipkan kolom saran dan kritik pada setiap variabel yang dapat diisi oleh responden untuk memberikan saran akan perbaikan aplikasi ini ke depannya.

Penelitian ini menggunakan lima variabel bebas dan satu variabel terikat sesuai dengan model penelitian Doll dan Torkzadeh (1988). Variabel bebas terdiri dari X1=Isi (content), X2= Bentuk (format), X3= Keakuratan (accuracy), $X 4=$ Kemudahan penggunaan (ease of use), dan $\mathrm{X} 5=$ Ketepatan waktu (timelines). Sedangkan variabel terikat berupa $Y=$ Kepuasan pengguna (user satisfaction).

Data yang diperoleh dari hasil kuesioner akan dianalisis menggunakan Structural Equation Method (SEM) dengan aplikasi smartPLS 3. Dalam proses analisis ini akan dilakukan uji validitas, uji realibilitas, dan uji hipotesis untuk melihat variabel mana yang berpengaruh terhadap kepuasan pengguna menggunakan aplikasi Phinisi di KPP Madya Balikpapan sehingga dapat menjadi perhatian untuk dikembangkan.

\section{HASIL PENELITIAN}

\subsection{Deskripsi Hasil Penelitian}

Total kuesioner yang disebarkan sebanyak 55 buah dengan kuesioner kembali sebanyak 49 buah. Sebanyak 6 kuesioner tidak kembali karena responden dinas atau cuti dan ada kuesioner yang hilang. Lebih lanjut, sebanyak 5 kuesioner tidak dapat digunakan sehingga penelitian ini akan dilanjutkan dengan menggunakan 44 kuesioner. Kuesioner yang tidak dapat dipergunakan tersebut disebabkan karena sebanyak 4 kuesioner terindikasi diisi oleh orang yang sama sehingga menghasilkan jawaban yang identik dan penulis akhirnya hanya mengambil salah satu kuesioner saja dalam penelitian ini, 1 kuesioner hanya terisi setengah (tidak selesai) dan 1 kuesioner sisanya memiliki jawaban yang sangat berbeda dengan yang lain sehingga pada saat pengujian menyebabkan data yang tidak valid.

Berdasarkan jenis kelamin, rincian 44 responden yang berpartisipasi dalam pengisian kuesioner diperoleh hasil bahwa proporsi responden berjenis kelamin perempuan dan laki-laki tidak terlalu jauh yaitu sebesar $55,55 \%$ dibanding $44,45 \%$ namun secara garis besar dapat dikatakan bahwa mayoritas responden dalam penelitian ini berjenis kelamin perempuan.

Hasil identifikasi responden berdasarkan usia diperoleh sebaran usia responden paling banyak terdapat pada rentang usia 31 sampai dengan 40 tahun sebanyak $43 \%$ diikuti dengan rentang usia 21 sampai dengan 30 tahun sebanyak $32 \%$. Selanjutnya terdapat
$16 \%$ responden dengan rentang usia 41 sampai dengan 50 tahun, $7 \%$ responden dengan usia 51 sampai dengan 60 tahun dan sisanya adalah responden di bawah usia 20 tahun sebanyak $2 \%$.

Identifikasi responden selanjutnya adalah menurut jabatan responden yang peneliti bagi menjadi tiga kategori jabatan, yaitu Kepala Seksi, Account Representative dan Pelaksana. Hasilnya dapat diketahui bahwa mayoritas responden sesuai dengan perkiraan pengguna terbesar aplikasi ini adalah Pelaksana dan Account Representative yaitu masingmasing sebesar 64\% dan 30\%. Sisanya yaitu Kepala Seksi dengan $7 \%$.

Salah satu penanda kesuksesan informasi dalam sebuah sistem yang bersifat voluntary use seperti aplikasi Phinisi ini menurut Sekundera (2006) adalah intention to use yang dapat dilihat dari seberapa sering pengguna menggunakan sistem ini untuk menunjang kegiatannya sehari-hari sehingga penulis menanyakan frekuensi penggunaan aplikasi Phinisi pada responden dalam kuesioner yang disebarkan. Hasilnya, mayoritas responden yaitu $63,6 \%$ menggunakan aplikasi ini setiap hari dalam satu minggu. Pada peringkat kedua ada $20,5 \%$ responden yang menggunakan aplikasi ini sebanyak tiga hingga empat kali dalam seminggu sedangkan sisanya yaitu sebanyak $15,9 \%$ responden menggunakan aplikasi ini sebanyak satu hingga dua kali dalam satu minggu.

\subsection{Pengujian Model}

Pengujian Model dilakukan dengan melihat hasil uji validitas dan realibilitas. Uji validitas sendiri terdiri dari dua tahapan, yaitu pengujian validitas konvergen dan validitas diskriminan. Validitas konvergen berhubungan dengan prinsip bahwa pengukur dari suatu variabel seharusnya berkorelasi tinggi sedangkan validitas diskriminan berhubungan dengan prinsip bahwa pengukur dari variabel yang berbeda seharusnya tidak berkorelasi tinggi (Abdillah dan Hartono 2015, 195).

Tahapan uji validitas yang pertama adalah pengujian validitas konvergen dengan melihat nilai outer loading pada tiap instrumen di tiap variabel. Rule of thumbs adalah lebih besar daripada 0,7 dan apabila skor ini ada di bawah 0,5 maka indikator yang ada harus dihapus dari variabelnya. Sedangkan apabila skor loading ada di antara 0,5-0,7 dan skor AVE ada di atas 0,5 maka indikator tersebut tidak perlu dihapus (Abdillah dan Hartono 2015, 206). Sedangkan menurut Hair, et al. seperti dikutip oleh Abdillah dan Hartono (2015), nilai outer loading adalah 0,3 dianggap sebagai faktor minimal, 0,4 dianggap semakin baik dan di atas 0,5 dianggap signifikan secara praktis.

Berdasarkan hasil pengujian diperoleh bahwa nilai AVE adalah di atas 0,5 untuk seluruh variabel pada model penelitian, termasuk pada variabel dengan indikator outer loading di antara 0,5 dan 0,7, sehingga sesuai dengan pernyataan Abdillah dan Hartono $(2015,206)$ seluruh indikator yang skor outer loadingnya berada di antara 0,5 dan 0,7 tidak dihilangkan. 
Tahap pengujian untuk melihat validitas variabel selanjutnya adalah pengujian validitas diskriminan dengan melihat skor cross loading setiap indikator. Pengujian validitas diskriminan berhubungan dengan prinsip bahwa pengukur dari variabel yang berbeda seharusnya tidak berkorelasi tinggi (Abdillah dan Hartono 2015, 195). Lebih lanjut, Abdillah dan Hartono (2015, 195) mengutip Hartono (2008) menyatakan bahwa "validitas diskriminan terjadi jika dua instrumen yang berbeda yang mengukur dua konstruk yang diprediksi tidak berkorelasi menghasilkan skor yang memang tidak berkorelasi". Hasil pengujiannya dapat dilihat pada tabel di bawah ini.

Tabel 2. Hasil Pengujian Cross Loading

\begin{tabular}{|c|c|c|c|c|c|c|}
\hline & Isi & Bentuk & Akurasi & $\begin{array}{c}\text { Kemuda } \\
\text { han }\end{array}$ & $\begin{array}{c}\text { Ketepatan } \\
\text { Waktu }\end{array}$ & $\begin{array}{c}\text { Kepuasan } \\
\text { Pengguna }\end{array}$ \\
\hline Isi1 & 0,906 & 0,571 & 0,535 & 0,669 & 0,565 & 0,741 \\
\hline Isi3 & 0,831 & 0,496 & 0,456 & 0,385 & 0,397 & 0,563 \\
\hline Btk2 & 0,559 & 0,899 & 0,438 & 0,686 & 0,721 & 0,769 \\
\hline Btk3 & 0,502 & 0,826 & 0,368 & 0,471 & 0,487 & 0,598 \\
\hline $\begin{array}{c}\text { Akr } \\
1\end{array}$ & 0,387 & 0,467 & 0,804 & 0,483 & 0,526 & 0,627 \\
\hline $\begin{array}{c}\text { Akr } \\
2\end{array}$ & 0,466 & 0,266 & 0,793 & 0,516 & 0,486 & 0,601 \\
\hline $\begin{array}{c}\text { Akr } \\
4\end{array}$ & 0,514 & 0,383 & 0,793 & 0,538 & 0,537 & 0,651 \\
\hline $\begin{array}{c}\text { Md } \\
\text { h1 }\end{array}$ & 0,573 & 0,630 & 0,484 & 0,828 & 0,723 & 0,777 \\
\hline $\begin{array}{c}\text { Md } \\
\text { h2 }\end{array}$ & 0,440 & 0,535 & 0,542 & 0,818 & 0,699 & 0,740 \\
\hline $\begin{array}{c}\text { Md } \\
\text { h3 }\end{array}$ & 0,560 & 0,559 & 0,596 & 0,876 & 0,849 & 0,838 \\
\hline \begin{tabular}{c} 
Tpt1 \\
\hline Tpt2
\end{tabular} & 0,515 & 0,600 & 0,468 & 0,751 & 0,835 & 0,768 \\
\hline \begin{tabular}{c} 
Tpt3 \\
\hline
\end{tabular} & 0,555 & 0,604 & 0,628 & 0,787 & 0,838 & 0,823 \\
\hline
\end{tabular}

Sebuah indikator dinyatakan valid apabila memiliki skor loading factor tertinggi kepada variabel yang dituju daripada loading factor kapada variabel yang lain. Tabel 2 di atas menunjukkan bahwa seluruh indikator yang ada pada masing-masing variabel tersisa telah valid karena masing-masing indikator memiliki skor loading factor yang tertinggi kepada variabel yang ditujunya daripada kepada variabel lain. Hasil pengujian tersebut juga sekaligus menyimpulkan bahwa seluruh variabel dalam penelitian ini telah memenuhi syarat validitas konvergen dan validitas diskriminan.

Setelah uji validitas dilakukan, selanjutnya dilakukan uji reliabilitas untuk mengukur konsistensi internal alat ukur (Abdillah dan Hartono 2015, 196). Meskipun demikian, Cooper, et al. (2006) seperti dikutip oleh Abdillah dan Hartono (2015) menyatakan bahwa sesungguhnya uji konsistensi internal ini tidak mutlak dilakukan apabila validitas variabel telah terpenuhi, karena variabel yang valid pasti reliabel namun variabel yang reliabel belum tentu valid.

Pengujian konsistensi internal ini dilakukan dengan dua alat ukur yaitu cronbach's alpha dan composite reliability. Menurut Chin (1995) seperti dikutip oleh Abdillah dan Hartono (2015, 195), cronbach's alpha mengukur batas bawah reliabilitas sebuah variabel sedangkan composite reliability mengukur nilai sesungguhnya dari reliabilitas sebuah variabel. Meskipun demikian, Salisbury, Chin, Gopal dan Newsted (2002) seperti dikutip oleh Abdillah dan Hartono $(2015,196)$ menyatakan bahwa "composite reliability dinilai lebih baik dalam mengestimasi konsistensi internal suatu konstruk." Menurut Hair, et al. (2008) seperti dikutip oleh Abdillah dan Hartono (2015), rule of thumbs nilai alpha maupun composite reliability adalah 0,7 meskipun nilai 0,6 masih dapat diterima. Hasil pengujian realibilitas dapat dilihat pada tabel 3 berikut.

Tabel 3. Hasil Pengujian Realibilitas

\begin{tabular}{|l|c|c|}
\hline & $\begin{array}{c}\text { Cronbach's } \\
\text { Alpha }\end{array}$ & $\begin{array}{c}\text { Composite } \\
\text { reliability }\end{array}$ \\
\hline Isi & 0,683 & 0,861 \\
\hline Bentuk & 0,663 & 0,854 \\
\hline Akurasi & 0,712 & 0,839 \\
\hline Kemudahan & 0,793 & 0,879 \\
\hline $\begin{array}{l}\text { Ketepatan } \\
\text { Waktu }\end{array}$ & 0,796 & 0,880 \\
\hline $\begin{array}{l}\text { Kepuasan } \\
\text { Pengguna }\end{array}$ & 0,919 & 0,931 \\
\hline
\end{tabular}

Tabel 3 di atas, menunjukkan bahwa seluruh variabel yang ada memiliki nilai alpha di atas 0,6 sehingga dapat dikatakan bahwa seluruh variabel dalam penelitian ini adalah andal. Kemudian untuk skor composite reliabilty masing-masing variabel semuanya memiliki nilai di atas 0,7 sehingga dapat dikatakan bahwa seluruh variabel yang ada adalah andal.

\subsection{Pengujian Hipotesis}

Pengujian selanjutnya adalah pengujian hipotesis yang pada penelitian ini menggunakan uji path coefficient dengan proses bootstrapping melalui aplikasi SmartPLS 3. Menurut Ghazali dan Latan (2015) seperti dikutip oleh Kurniawan $(2015,68)$ pengaruh antar variabel dinyatakan signifikan apabila $t_{\text {statistic }}$ yang dihasilkan variabel lebih besar daripada $t_{\text {value }}$ sebesar 1,65 pada tingkat signifikansi (p) 10\%, 1,96 pada tingkat signifikansi (p) 5\% dan 2,58 pada tingkat signifikansi ( $p$ ) 1\%. Sedangkan menurut Abdillah dan Hartono (2015, 197) seperti mengutip Hair, et al. (2008), skor koefisien path yang ditunjukkan oleh nilai $t_{\text {statistic }}$ harus di atas 1,96 untuk hipotesis dua ekor dan di atas 1,64 untuk hipotesis satu ekor. Untuk nilai signifikansi (p) yang sering digunakan menurut Morissan $(2015,288)$ adalah $0,05,0,01$, dan 0,001. Ketiga level signifikansi ini berarti peluang memperoleh hubungan yang terukur sebagai hasil kesalahan sampling adalah 5/100, 1/100, dan $1 / 1000$.

Selain nilai $t_{\text {statistic }}$ dan $p$ values di atas, yang perlu diperhatikan dalam pengujian hipotesis menggunakan aplikasi SmartPLS ini adalah nilai Original Sample (O) yang menunjukkan hubungan positif atau negatif antar variabel. Apabila Original Sample ini positif maka hubungan antar variabel juga positif, begitu pula sebaliknya. Hasil output path coefficient sekaligus hasil pengujian hipotesis pada penelitian ini dapat dilihat pada tabel 4.

Berdasarkan hasil pengujian koefisien path pada tabel 4 di bawah ini, dapat dilihat bahwa seluruh 
seluruh hipotesis yang diujikan memperoleh skor Original Sample positif yang berarti seluruh variabel bebas yang diuji mempunyai hubungan positif dengan variabel terikatnya. Selain itu nilai $t_{\text {statistic }}$ yang berada di atas 1,64 untuk hipotesis satu ekor serta nilai $p$ yang seluruhnya $<0,001$ menunjukkan bahwa seluruh hipotesis terdukung dengan signifikansi 0,001 atau $0,1 \%$. Nilai Original Sample terbesar terdapat pada hubungan antara variabel kemudahan dengan kepuasan pengguna serta hubungan antara variabel ketepatan waktu dengan variabel kepuasan pengguna.

Tabel 4. Hasil Pengujian Path Coefficient

\begin{tabular}{|l|c|c|c|}
\hline & $\begin{array}{c}\text { Original } \\
\text { Sample (O) }\end{array}$ & $\begin{array}{c}\text { T Statistics } \\
(|\mathrm{O} / \mathrm{STDEV}|)\end{array}$ & $\begin{array}{c}\mathrm{P} \\
\text { Values }\end{array}$ \\
\hline $\begin{array}{l}\text { Isi -> Kepuasan } \\
\text { Pengguna }\end{array}$ & 0,170 & 8,456 & 0,000 \\
\hline $\begin{array}{l}\text { Bentuk -> } \\
\text { Kepuasan } \\
\text { Pengguna }\end{array}$ & 0,177 & 7,488 & 0,000 \\
\hline $\begin{array}{l}\text { Akurasi -> } \\
\text { Kepuasan } \\
\text { Pengguna }\end{array}$ & 0,224 & 8,482 & 0,000 \\
\hline $\begin{array}{l}\text { Kemudahan -> } \\
\text { Kepuasan } \\
\text { Pengguna }\end{array}$ & 0,296 & 17,530 & 0,000 \\
\hline $\begin{array}{l}\text { Ketepatan } \\
\text { Waktu -> } \\
\text { Kepuasan } \\
\text { Pengguna }\end{array}$ & 0,296 & 14,583 & 0,000 \\
\hline
\end{tabular}

Berdasarkan hasil uji path coefficient pada tabel 4 di atas, maka dapat dijelaskan hasil pengujian hipotesis sebagai berikut:

1. Hipotesis 1: Pengaruh Variabel Isi (Content) Terhadap Variabel Kepuasan Pengguna (User Satisfaction)

Pengujian hipotesis yang pertama adalah pengujian pengaruh variabel isi (content) aplikasi Phinisi terhadap kepuasan pengguna aplikasi pada KPP Madya Balikpapan. Hasil pengujian hipotesis menunjukkan bahwa nilai Original Sample (O) mendapatkan skor positif sebesar 0,170 dan skor $t_{\text {statistik }}$ adalah sebesar 8,456. Nilai $t_{\text {statistik }}$ ini berada di atas $t_{\text {tabel }}$ untuk hipotesis satu ekor yaitu sebesar 1,64 sehingga dapat dipastikan bahwa variabel isi berpengaruh positif dan signifikan terhadap variabel kepuasan pengguna. Nilai p sebagai nilai signifikansi menunjukkan skor 0,000 sehingga $p<0,001$ yang berarti signifikansi pada hipotesis ini adalah sebesar 0,001 atau $0,01 \%$. Pengaruh positif dalam hipotesis ini menunjukkan bahwa semakin besar persepsi positif pengguna aplikasi terhadap isi aplikasi ini, semakin besar pula persepsi kepuasan pengguna aplikasi Phinisi di KPP Madya Balikpapan.

2. Hipotesis 2: Pengaruh Variabel Bentuk (Format) Terhadap Variabel Kepuasan Pengguna (User Satisfaction)

Pengujian hipotesis kedua adalah menguji apakah bentuk atau tampilan dari aplikasi Phinisi ini berpengaruh positif terhadap kepuasan pengguna aplikasi. Hasil pengujian hipotesis menunjukkan skor Original Sample (O) bernilai positif sebesar 0,177 serta nilai $t_{\text {statistik }}$ sebesar 7,488 yang berada di atas nilai tabel untuk hipotesis satu ekor yaitu sebesar 1,64 sehingga dapat dipastikan bahwa variabel bentuk berpengaruh positif dan signifikan terhadap variabel kepuasan pengguna. Nilai signifikansi ditunjukkan oleh nilai $p$ yang berada pada skor 0,000 artinya $p<0,001$ yang menunjukkan signifikansi dari hipotesis ini adalah sebesar 0,001 atau $0,1 \%$. Pengaruh positif dalam hipotesis ini menunjukkan bahwa semakin besar persepsi positif pengguna aplikasi terhadap bentuk aplikasi ini, semakin besar pula persepsi kepuasan pengguna aplikasi Phinisi di KPP Madya Balikpapan.

3. Hipotesis 3: Pengaruh Variabel Keakuratan (Accuracy) Terhadap Variabel Kepuasan Pengguna (User Satisfaction)

Pengujian yang ketiga adalah menguji apakah variabel keakuratan informasi dari aplikasi Phinisi ini berpengaruh positif terhadap kepuasan pengguna aplikasi. Hasil pengujian dalam tabel IV.20 menunjukkan bahwa skor Original Sample (O) bernilai positif sebesar 0,224 serta hasil tstatistik sebesar 8,482 yang berada di atas nilai tabel untuk hipotesis satu ekor yaitu sebesar 1,64 sehingga dapat dipastikan bahwa variabel keakuratan berpengaruh positif dan signifikan terhadap variabel kepuasan pengguna. Nilai signifikansi ditunjukkan oleh nilai $\mathrm{p}$ sebesar 0,000 yang berarti $p<0,001$ sehingga dapat dikatakan bahwa hipotesis ketiga terdukung dengan nilai signifikansi sebesar 0,001 atau 0,1\%. Pengaruh positif dalam hipotesis ini menunjukkan bahwa semakin besar persepsi positif pengguna aplikasi terhadap keakuratan informasi yang dihasilkan oleh aplikasi ini, semakin besar pula persepsi kepuasan pengguna aplikasi Phinisi pada KPP Madya Balikpapan.

4. Hipotesis 4: Pengaruh Variabel Kemudahan (Ease of Use) Terhadap Variabel Kepuasan Pengguna (User Satisfaction)

Pengujian yang keempat adalah menguji apakah variabel kemudahan penggunaan aplikasi Phinisi ini berpengaruh positif terhadap kepuasan pengguna aplikasi. Hasil pengujian dalam tabel IV.20 menunjukkan bahwa skor Original Sample (O) bernilai positif sebesar 0.296 serta hasil $t_{\text {statistik }}$ sebesar 17,530 yang berada di atas nilai tabel untuk hipotesis satu ekor yaitu sebesar 1,64 sehingga dapat dipastikan bahwa variabel kemudahan penggunaan aplikasi berpengaruh positif dan signifikan terhadap variabel kepuasan pengguna. Nilai signifikansi ditunjukkan oleh nilai $p$ sebesar 0,000 yang berarti $p<0,001$ sehingga dapat dikatakan bahwa hipotesis ketiga terdukung dengan nilai signifikansi sebesar 0,001 atau $0,1 \%$. Pengaruh positif dalam hipotesis ini menunjukkan bahwa semakin besar persepsi positif pengguna aplikasi terhadap kemudahan 
penggunaan aplikasi Phinisi, maka semakin besar pula persepsi kepuasan pengguna aplikasi Phinisi pada KPP Madya Balikpapan.

5. Hipotesis 5: Pengaruh Variabel Ketepatan Waktu (Timeliness) Terhadap Variabel Kepuasan Pengguna (User Satisfaction)

Pengujian yang kelima adalah menguji apakah variabel ketepatan waktu aplikasi Phinisi ini berpengaruh positif terhadap kepuasan pengguna aplikasi. Hasil pengujian dalam tabel IV.20 menunjukkan bahwa skor Original Sample (O) bernilai positif sebesar 0.296 serta hasil $t_{\text {statistik }}$ sebesar 14,583 yang berada di atas nilai $t_{\text {tabel }}$ untuk hipotesis satu ekor yaitu sebesar 1,64 sehingga dapat dipastikan bahwa variabel kemudahan penggunaan aplikasi berpengaruh positif dan signifikan terhadap variabel kepuasan pengguna. Nilai signifikansi ditunjukkan oleh nilai $p$ sebesar 0,000 yang berarti $p<0,001$ sehingga dapat dikatakan bahwa hipotesis ketiga terdukung dengan nilai signifikansi sebesar 0,001 atau $0,1 \%$. Pengaruh positif dalam hipotesis ini menunjukkan bahwa semakin besar persepsi positif pengguna aplikasi terhadap ketepatan waktu dari informasi yang dihasilkan oleh aplikasi Phinisi, maka semakin besar pula persepsi kepuasan pengguna aplikasi Phinisi pada KPP Madya Balikpapan.

\subsection{Pembahasan}

Berdasarkan hasil pengujian hipotesis dapat dilihat bahwa hipotesis pertama diterima sesuai dengan Agustina (2006) yang meneliti tingkat kepuasan pemakai website Universitas Bina Darma menggunakan pendekatan Model Kepuasan Pemakai Akhir Komputer dan memperoleh hasil variabel isi ini berpengaruh secara signifikan terhadap kepuasan pengguna. Begitu pula penelitian yang dilakukan oleh Rasman (2012) yang meneliti hubungan unsur-unsur End User Computing Satisfaction terhadap kepuasan pengguna Sistem Informasi Rumah Sakit Di Rumah Sakit Umum Daerah Kota Depok Tahun 2012. Penelitian Rasman ini juga memperoleh hasil bahwa variabel isi berpengaruh secara signifikan terhadap kepuasan pengguna Sistem Informasi walaupun dibandingkan variabel lain, tingkat kepuasan pengguna terhadap isi dari Sistem Informasi ini terbilang paling rendah.

Hasil hipotesis kedua menunjukkan diterima sesuai dengan penelitian Agustina (2006) dan Rasman (2012) yang juga menunjukkan pengaruh yang signifikan antara variabel bentuk dengan kepuasan pengguna akhir. Penelitian yang dilakukan oleh Rasman (2012) menghasilkan kesimpulan bahwa variabel bentuk memiliki tingkat kepuasan pengguna yang tertinggi dibandingkan dengan variabel lain.

Hasil penelitian hipotesis yang ketiga ini sejalan dengan hasil penelitian dari peneliti sebelumnya yaitu Sekundera (2006), Agustina (2006) dan Rasman (2012) yang juga menunjukkan bahwa variabel keakuratan informasi ini berpengaruh positif dan signifikan terhadap kepuasan pengguna akhir.
Hasil penelitian hipotesis yang keempat ini menunjukkan hasil yang sama dengan hasil penelitian dari peneliti sebelumnya yaitu Sekundera (2006), Agustina (2006) dan Rasman (2012) yang juga menunjukkan bahwa variabel kemudahan penggunaan ini berpengaruh positif dan signifikan terhadap kepuasan pengguna akhir. Hasil penelitian ini menunjukkan bahwa semakin mudah sebuah sistem dioperasikan oleh pengguna, maka tingkat kepuasan pengguna terhadap sistem tersebut semakin meningkat.

Hasil penelitian hipotesis yang kelima ini menunjukkan hasil yang sama dengan hasil penelitian dari peneliti sebelumnya yaitu Sekundera (2006), Agustina (2006) dan Rasman (2012) yang juga menunjukkan bahwa variabel ketepatan waktu ini berpengaruh positif dan signifikan terhadap kepuasan pengguna akhir.

\section{KESIMPULAN DAN SARAN}

Berdasarkan hasil pengujian hipotesis pada bagian 4 di atas, maka dapat disimpulkan bahwa variabelvariabel yang memiliki pengaruh positif terhadap kepuasan pengguna (user satisfaction) dalam memanfaat aplikasi Phinisi di KPP Madya Balikpapan adalah variabel isi (content), variabel bentuk (format), variabel keakuratan (accuracy), variabel kemudahan (ease of use), dan variabel ketepatan waktu (timeliness).

Berdasarkan hasil kesimpulan di atas, maka dalam mengembangkan aplikasi Phinisi di KPP Madya Balikpapan perlu di perhatikan variabel-variabel yang telah disebutkan, karena variabel-variabel tersebut memberikan pengaruh yang posistif terhadap penggunaan aplikasi Phinisi. Selain itu, DJP perlu mempertimbangkan penggunaan aplikasi Phinisi secara nasional mengingat banyaknya manfaat yang bisa diperoleh dari penggunaan aplikasi tesebut.

\section{IMPLIKASI DAN KETERBATASAN}

Beberapa keterbatasan penelitian dalam penelitian ini adalah sebagai berikut:

1. Penelitian ini menggunakan metode penelitian kuantitatif sehingga pembahasan masalahnya pun tidak bisa mendalam. Data yang didapat juga sangat terbatas yaitu data responden dari satu kantor, sehingga data yang ada tidak menyentuh pengguna aplikasi di luar KPP Madya Balikpapan. Kurangnya waktu penelitian menjadi pertimbangan penulis membatasi responden dari lingkup yang lebih besar misalnya lingkup satu wilayah Kanwil DJP Kalimantan Timur dan Utara.

2. Jumlah responden yang rencananya akan diambil sebagai populasi menurun secara signifikan karena sejak rencana penelitian ini disetujui (Oktober 2016) hingga penelitian ini berjalan (Desember 2016) telah terjadi beberapa kali mutasi pegawai yang dengan jumlah pegawai KPP Madya 
Balikpapan yang keluar lebih besar daripada jumlah pegawai yang masuk sehingga mempengaruhi jumlah responden secara keseluruhan.

3. Keterbatasan pengembangan model penelitian yang dilakukan penulis membuat variabel yang ada memiliki keterbatasan jumlah indikator. Begitu pula variabel kepuasan pengguna yang tidak memiliki indikator sendiri karena peneliti masih berpatokan pada model asli yang dikembangkan oleh Doll dan Torkzadeh (1988).

4. Aplikasi pengolah data yang penulis gunakan, yaitu SmartPLS 3 tidak mengakomodasi pengaruh antar variabel secara simultan, sehingga penulis hanya meneliti pengaruh antar variabel secara parsial saja.

Untuk penelitian selanjutnya, disarankan agar dapat memperbesar populasi penelitian untuk penelitian sejenis penelitian ini. Selain itu untuk peneliti yang akan mengembangkan penelitian dengan model EUCS ini dapat lebih menambahkan banyak pertanyaan pada variabel yang ada atau mengkombinasikannya dengan model yang lain sehingga dihasilkan data yang lebih baik. Kombinasi pengolahan data dengan beberapa software pengolah data misalnya dengan SPSS akan menghasilkan hasil penelitian yang tidak hanya secara parsial tapi juga secara simultan.

\section{DAFTAR PUSTAKA}

Abdillah, Wiily, dan Jogiyanto Hartono. 2015. Partial Least Square (PLS) - Alternatif Structural Equation Modelling (SEM) dalam Penelitian Bisnis. Yogyakarta: Penerbit Andi.

Agustina, Merry. 2006. “Mengukur Tingkat Kepuasan Pemakai Website Universitas Bina Darma Menggunakan Pendekatan Model Kepuasan Pemakai Akhir Komputer." Program Magister Manajemen Konsentrasi Manajemen Sistem Informasi Universitas Bina Darma Palembang (Universitas Bina Darma).

Arikunto, Suharsimi. 2002. Prosedur Penelitian : Suatu Pendekatan Praktek. Jakarta : PT. Rineka Cipta.

Chin, Wynne W., dan Mattthew K. O. Lee. 2000. “A Proposed Model and Measurement Instrument For The Formation Of IS Satisfaction: The Case of End-User Computing Satisfaction." Proceedings of The Twenty-First International Conference On Information System.

Cooper, D.R., dan P.S Schindler. 2006. Business Research Methods (9 ed.). New York: Irwin/McGraw-Hill.

D, Roger Wimmer, dan Joseph R Dominick. 2011. Mass Media Research : An Introduction. Wadsworth.

Davis, B Gordon. 1985. Kerangka Dasar Sistem Informasi Manajemen, Bagian I Pengantar.
Jakarta : Cetakan Ketiga: PT Pustaka Binaman Pressindo.

Doll, William J., dan Gholamreza Torkzadeh. 1988. "The Measurement of End User Computing Satisfaction." MIS Quarterly.

Ghozali, Imam, dan Hengky Latan. 2015. Partial Least Squares: Konsep, teknik dan Aplikasi Menggunakan Program SmartPLS 3.0 untuk Penelitian Empiris. Edisi 2. Semarang: Badan Penerbit Universitas Diponegoro.

Hill, Mary Callahan, dan W. Alan Barnes. 2011. "EndUser Computing Applications." The CPA Journal.

Kurniawan, Hanif Dwi. 2015. "Analisis Faktor Yang Mempengaruhi Kepuasan Pengguna Portal Pengguna Jasa DJBC Dengan Model Kesuksesan Sistem Informasi DeLone dan McLean (Studi Kasus Di KPU Bea dan Cukai Tipe A Tanjung Priok)." Program Diploma IV Akuntansi STAN.

Kuswantoro, Ari. 2016. “Analisis Pengaruh Persepsi Kemanfaatan Dan Persepsi Kemudahan Penggunaan Terhadap Penerimaan MPN-Info Di Lingkungan Kanwil DJP Sulawesi Selatan, Barat, Dan Tenggara." Program Diploma IV Akuntansi STAN.

Morissan. 2015. Metode Penelitian Survei. Jakarta: Prenadamedia Group.

Rasman, Yoel Indra Kusuma. 2012. “Gambaran Hubungan Unsur-Unsur End User Computing Satisfaction Terhadap Kepuasan Pengguna Sistem Informasi Rumah Sakit Di Rumah Sakit Umum Daerah Kota Depok Tahun 2012." Skripsi.

Raymond McLeod, Jr, dan George P. Schell. 2008. Sistem Informasi Manajemen Edisi 10. Jakarta: Salemba Empat.

Republik Indonesia. Surat Edaran Direktur Jenderal Pajak Nomor SE-08/PJ/2016 tanggal 26 Februari 2016 Tentang Pedoman Pengelolaan End User Computing (EUC).

Romney, Marshall, dan Paul Steinbart. 2006. Accounting Information System : 10th edition. New Jersey: Pearson Prentice Hall.

Sekundera, Charlesto. 2006. "Analisis Penerimaan Pengguna Akhir Dengan Menggunakan Technology Acceptance Model dan End User Computing Satisfaction Terhadap Penerapan Sistem Core Banking Pada Bank ABC." Tesis.

Sugiyono. 2016. Metode Penelitian Kuantitatif Kualitatif dan R\& D. Bandung: Alfabeta. 